\title{
EVALUATION OF A.E. KULAKOVSKY'S WRITING DURING THE NASCENT PERIOD OF YAKUTSK LITERARY CRITICISM
}

\author{
AVALIAÇÃO DA ESCRITA DE A.E. KULAKOVSKY DURANTE O PERÍODO \\ NASCENTE DE CRÍTICA LITERÁRIA DE YAKUTSK
EVALUACIÓN DE LA ESCRITURA DE A.E. KULAKOVSKY DURANTE EL PERÍODO NACIENTE DE LA CRÍTICA LITERARIA DE YAKUTSK

Svetlana DARBASOVA ${ }^{1}$

\begin{abstract}
The research presents a study on the issue of evaluating the criticism of A.E. Kulakovsky (1877-1926), the Yakut literature founder, at the stage of Yakut literature formation. Criticism, from the first critic reviews to contemporary monographs, reflect the entire path of the Yakut literary criticism development. In the 1920s, young criticism took a difficult path of transition from literature to field of political struggle. The cultural, historical, and sociopolitical situation in the country resulted in opposite opinions of critics and writers, from that period, about classics works of the Yakut literature. The study is grounded on the synaestheticism principle. The results of the study consist in the analysis and systematization of the first critical comments, reviews, and articles and previously unrevealed materials from periodicals of this time, which allows identifying the peculiarities of the perception of the first poet's creative heritage by critics and writers of the emerging Yakut literature.
\end{abstract}

KEYWORDS: Yakut criticism. Pre-revolutionary writers. Bourgeois nationalism. Nihilistic approach. Critical article.

RESUMO: A pesquisa apresenta o estudo da questão da avaliação da crítica de A.E. Kulakovsky (1877-1926), o fundador da literatura Yakut, na fase de formação da literatura Yakut. A crítica, desde as primeiras críticas às monografias contemporâneas, reflete todo o caminho de desenvolvimento da crítica literária Yakut. Na década de 1920, a jovem crítica percorreu um dificil caminho de transição da literatura para o campo da luta política. A situação cultural, histórica e sociopolítica do país resultou em opiniões contrárias de críticos e escritores da época, sobre a obra dos clássicos da literatura Yakut. O estudo é baseado no princípio do sinestetismo. Os resultados do estudo consistem na análise e sistematização dos primeiros comentários críticos, resenhas, artigos e materiais até então não revelados de periódicos desse período, o que permite identificar as peculiaridades da percepção do patrimônio criativo, do primeiro poeta, por críticos e escritores da emergente literatura Yakut.

PALAVRAS-CHAVE: Críticas Yakut. Escritores pré-revolucionários. Nacionalismo burguês. Abordagem niilística. Artigo crítico.

${ }^{1}$ North-Eastern Federal University named after M.K. Ammosov (NEFU), Yakutsk - Russia. Senior Associate of the Kulakovsky Institute. ORCID: https://orcid.org/0000-0002-3691-4483. E-mail: svetlanadarbasova@yahoo.com 
RESUMEN: La investigación presenta el estudio del tema de la evaluación de la crítica de A.E. Kulakovsky (1877-1926), el fundador de la literatura Yakut, en la etapa de formación de la literatura Yakut. La crítica, desde las primeras reseñas críticas hasta las monografías contemporáneas, refleja todo el camino del desarrollo de la crítica literaria Yakut. En la década de 1920, la crítica joven tomó un difícil camino de transición de la literatura al campo de la lucha política. La situación cultural, histórica y sociopolítica del país generó opiniones opuestas de críticos y escritores de ese periodo sobre la obra de los clásicos de la literatura de Yakut. El estudio se basa en el principio de sinestesismo. Los resultados del estudio consisten en el análisis y sistematización de los primeros comentarios críticos, reseñas y artículos y materiales inéditos de publicaciones periódicas de este período, lo que permite identificar las peculiaridades de la percepción de la herencia creativa del primer poeta por parte de críticos y escritores de la literatura emergente de Yakut.

PALABRAS CLAVE: Crítica de Yakut. Escritores prerrevolucionarios. Nacionalismo burgués. Enfoque nihilista. Artículo crítico.

\section{Introduction}

In the context of globalization, the culture of indigenous minorities undergoes unification and leveling in the general process of human development. It is then that the issues of spiritual self-identification and national values come to the fore, which do not allow peoples to get lost in the vast world. In this regard, A.E. Kulakovsky's artistic and scientific heritage is recognized by the Yakuts as the conceptual-paradigmatic and culturalphilosophical basis of the national culture. The depth of the philosophical issues formulated by him at the beginning of the 20th century, the enduring value of culturological ideas, and the universality of knowledge in many scientific areas are interpreted as the most important spiritual and moral sources of the Yakut people's culture (SIVTCEVA-MAKSIMOVA; SIVTSEVA, 2019). The creative heritage of the classic of literature and the outstanding thinker of the 20th century, which goes back to the idea of Eurasianism, is not only the Yakuts' national heritage, but also a valuable contribution to the formation of the humanitarian and moral space of peoples, which began to form in Russian literature and philosophy from the middle of the 19th century.

Yakut literary criticism originated in the $1920 \mathrm{~s}$ in periodicals. The first critical speeches appeared in republican newspapers and magazines, which were caused by the urgent need to highlight the literary process. With the exception of few articles, written in traditional genres of criticism, these were reflections, comments, and reviews of young writers, attempts to analyze the creative heritage of pre-revolutionary writers. The original literary criticism was interesting to readers for its courageous reasoning, unconventional aesthetic taste and the 
desire to understand the artistic word based on their own convictions. In newspaper and magazine articles, young writers' debate about the development of the emerging Yakut literature and criticism unfolded. Researcher of the history of Yakut literary criticism G.S. Syromyatnikov characterizes the criticism of this period as having a common ideological basis with Soviet literary criticism, whose goal was to direct literature along the path of serving the working people (SYROMYATNIKOV, 2017).

The initial period of the establishment of Yakut literary criticism represents a completely new stage in the development of the social consciousness, when critical battles contributed to the ideological and creative growth of young writers and critics, also brought up thoughtful and objective readers in their assessments. Despite adherence to Russian and partly Western cultural-philosophical views and theories, critics relied not on abstract, farfetched schemes in their judgments, but on their personal empirical and rational experience, which became the basis for the emergence of original critical thought. In addition to the burning literary problems, the subject of discussion was the attitude to the heritage of the first writers, who were called "pre-revolutionary writers-enlighteners". If researchers of the first Yakut poet's work say that “A.E. Kulakovsky's poetic heritage is the entire Yakut literature in its origins" (SIVTSEVA-MAKSIMOVA, 2005, p. 44), then the critical literature about his heritage is the entire complex path of the development of Yakut literary criticism. The change in assessments of Kulakovsky's poetic works, observed in the 1920s and 1930s, was due to the cultural and political situation in the country, depending on the party policy. Following the guidelines of the RAPP militant organization (Russian Proletarian Writers' Association), the principles of vulgar sociologism and totalitarian ideology, the young Yakut criticism went through almost the most difficult period of its development.

Based on the above, we put forward a working hypothesis of the study about the inextricable connection of criticism with social life, politics, and ideology with a pronounced character precisely at an early stage in the development of literature and criticism, based on the analysis of critical material about the first Yakut poet's work during the period of the birth of Yakut literary criticism.

The research purpose of studying the evaluation of A.E. Kulakovsky's work, by Yakut criticism in the 1920s and 1930s, is to give the most complete description of literary criticism based on his writings at the stage of the emergence of Yakut criticism regarding a historical and cultural approach. To achieve this objective, the task is to determine the logical nature of the simplified, at first glance, interpretation of the essence of literature by the first critics, identify the reasons for the struggle for the class purity of proletarian literature, their attitude 
to the literary heritage of pre-revolutionary writers and folklore, and explain mistakes and shortcomings in works that stem not only from the Yakut critics' poor theoretical training, but also from the development of the literary process as a whole.

\section{Literature review}

Articles dedicated to A.E. Kulakovsky's work, began to appear in the republican periodicals since the mid-1920s. In 1923, an article "The Yakuts' Literary Creativity" by a prominent public figure of that period, V.V. Nikiforov under the pseudonym Kyulyumnyur, was published in the Life of Nationalities journal. In Yakut literature review, the author calls Kulakovsky "the singer of the former better life of the Yakut people, their persistent struggle with the harsh climate", recognizing him as the second gifted poet after the author of the play "Manchaary tukun" (1905) (Robber Manchary) in the Yakut language (KYГLYUMNUR, 1991). Note that the author of the above-mentioned first play in the Yakut language is the author himself, thus Nikiforov considers himself the pioneer of Yakut literature. However, Kulakovsky's poem "Bayanai algyya" (Bayanai's Conjuration) was written in 1900, but published much later than the play by Kyyulumnyur. The article was published in Moscow and was not widely spread in Yakutia.

Vasily Nikanorovich Leontiev, a graduate of the Law Faculty of the Tomsk University, a member of the first scientific society "Sakha Keskile", stands out among the first critics who devoted their works to the analysis of A.E. Kulakovsky's writings. In the article "Literary Issues" (LEONTIEV, 1926a, p. 81-87), V. Leontiev was the first in the history of Yakut criticism who reviewed the young Yakut literature. The value of the work is not only in the objective translation of the content of the emerging literature, but also in determining its character, regarding the cultural and historical time. Leontiev notes the influence of Russian classical literature on the formation of the realistic genre and mentions its originality as a feature of pre-revolutionary literature, having developed based on folk songs and legends. In contrast to young critics who believed that the new literature should be grounded on class nature principles, the critic argues that the new literature should develop gradually, without drastic displacement of the former order by the new one and follow the principles of critical realism from "life to art", and not the other way around. Leontiev understood the further development of Yakut literary criticism correctly: he demanded that the historical conditions and social tasks should be considered when characterizing the current 
state of literature and criticism, but at the same time not throwing off highly professional samples of pre-revolutionary literature.

In the article "Is Kulakovsky a Poet?", addressing critics and writers, Leontiev says that the emerging literature should be treated "extremely carefully and delicately", that "there should be no place for reckless and arrogant critical speeches" (LEONTIEV, 1926b, p. 2123). The work is an analysis of the of M. Naltan's (M. I. Shadrin) review on the first volume of poetic works by A.E. Kulakovsky "Yrya-khohoon" (Poems and Songs). The collection of the poet's works in two volumes was published under the author's edition in 1924-25, and the title of the collection testifies to the transition of Yakut literature from song to literary traditions. Hence Naltan's statement that the first poet's creative work is based on poetic adjustment of folklore sources and that Kulakovsky is more a folklorist than a poet. Getting into polemics with the author of the review, Leontiev examines Lennroth's Kalevala and concludes that if Kalevala is a collection of adjusted Finnish folk songs-epics, then Kulakovsky's Yrya-khohoon is "the fruit of Kulakovsky's personal creativity as a poet" (LEONTIEV, 1926, p. 21-23).

Dividing the works from the Collection into three categories, Leontiev classifies the first Yakut poem "Bayanai algyya" (Bayanai's Conjuration) as songs recorded from the words of others, but poetically finished by the poet himself. "Buluuluu ungkuu" (1905) (Dance in the Vilyui way), "Bylyrgylyy algys" (1916) (Oath in the old way), and "Bylyrgy Sakha andagara" (1921) (An Old Yakut oath) are classified as the second category of poems and songs, compiled on the basis of legends and oral folk art which, while maintaining the content, are subject to complete poetic adjustment and represent an "outstanding poetry". As an illustrative material, he cites an excerpt from the oath recorded by Yastremsky, and compares it with the Kulakovsky's oath, noting the poetic merits of the last passage, where there is such a concept as an artistic image. The critic refers all other works to the third category exclusively written by Kulakovsky. Thus, 20 out of 24 songs belong to Kulakovsky, which excludes Naltan's definition: the author of the Collection is not an editor (diascevast), but a unique talented poet - this is Leontiev's conclusion.

Thus, the article presents not only the first classification of the poet's works, addressing the relationship between folklore and literature, but also lays the foundation for the study of the nature of the genre in Yakut literature, based on oral poetry, when the folklore works, undergoing the poet's artistic adjustment, established the genre classification of Yakut poetry. 
Next, let us briefly dwell on the article "Critical Notes on A.E. Kulakovsky's creative work" (1925), kept in the archives of the Yakutsk Scientific Center of the Russian Academy of Sciences (F.5, Op.2; L.162. L1. 3-4) (LEONTIEV, 1925). Here Leontiev discusses the nature of the emerging Yakut literature in a somewhat peculiar way. Speaking about the fact that before the appearance of Pushkin in the literary horizon, Russian literature according to V.G. Belinsky, was a "transplant" and not an "indigenous fruit", he sees the reason in the fact that $83 \%$ of Russian writers were noblemen by birth. Yakut literature, wholly grown based on folk background, had to a priori to become an "indigenous fruit" - original and national (LEONTIEV, 1925) due to the fact that the first writers came from the poor or middle strata of the population, expressing not the noble, but the popular worldview. As for the creativity of the originally national poet A.E. Kulakovsky, Leontiev notes that the poet was a passionate preacher of sound realism, not only objectively reflecting reality, but also indicating the means for improving it (LEONTIEV, 1925). It is worth agreeing that this was the first assessment of the poet's artistic method in Yakut criticism because of the analysis of his poetic works.

We find the first references in the central press in "Essays on the Study of the Yakut Region", published by the East Siberian Department of the Russian Geographical Society (Yakut section), dedicated to the 5th anniversary of the Yakut ASSR, edited by V.I. Podgorbunsky, P.P. Khoroshikh, and V.A. Krotova. In the Preface to the Collection, the authors note that

from the very first steps of its work, the Yakut section of the VSORGO (East-Siberian Department of the Russian Geographical Society) realized the need to publish a collection in which the results of the achievements of scientific thought in the field of knowledge of Yakutia would be recorded (RUSSIA, 1990, p. 4).

The article, by the famous archaeologist, ethnographer, and historian of Yakutia I.D. Novgorodov (1899-1972), is a recorded report at a meeting of the Yakut section of Society, dedicated to the half-year anniversary of A.E. Kulakovsky's death. In addition to biographical information, the article defines Kulakovsky as the founder of Yakut literature. Novgorodov writes that since 1900 A.E. Kulakovsky's poetic and research work, as well as the year of the appearance of the poem "Bayanai algyya" (Bayanai's Conjuration), is "the date of the birth of Yakut fiction, the first robin of spring of which is "Bayanai algyya" (RUSSIA, 1990). However, the editors noted that such an early publication of materials about Kulakovsky will inevitably lead to a certain incompleteness and shortcomings, bearing in mind, in our opinion, 
the polemic that existed in Yakut circles about the work from which the Yakut literature originated (RUSSIA, 1990, p. 39).

It also contains an article by the famous scientist-ethnographer P.P. Khoroshikh "A.E. Kulakovsky's Scientific and Literary Heritage”, where the author speaks about Kulakovsky as an ethnographer who occupies an honorable place among researchers with Siberian indigenous tribes' backgrounds (RUSSIA, 1990, p. 40). The author presents a list of published works and manuscripts as evidence of the long-term, tireless, and varied activity of the researcher, including 11 items. In addition, he gives 5 titles of articles and notes about Kulakovsky at that period. In fact, this is the beginning of a bibliography of a poet and a researcher, initiated by a scientist from the central region. We consider it necessary to emphasize that under the titles of the works, a link to their review is also given, and there is the name of V.N. Leontiev in three of them.

As for the local press, starting from the mid-1920s, changes began to take place in the assessment of the pre-revolutionary writers' work under the influence of vulgar sociological criticism, emphasizing the social aspect of art and openly announcing a break with the classical literary heritage. The members of the Young Bolshevik literary group, guided by RAPP's principles, accused the poet of Malthusianism and bourgeois nationalism. V. N. Protodyakonov called this difficult period in the history of Yakut criticism - the period of cultural distancing from the roots and origins of popular culture, the vigilant control of the party apparatus over the artistic intelligentsia's activities. According to the researcher, at this time, highly artistic works that reflect life with genuine interest and philosophical depth, gave way to works of "literature of fact" in the niche of literature (PROTODYAKONOV, 2009). N. M. Zabolotsky, a representative of the literary criticism of this period, called the attitude towards the first writers' work as a manifestation of the strongest influence of the vulgar sociologism prevailing in the Soviet Union. However, the writer differentiated the actions of novice critics from the "nihilistic psychosis", which had even more acute features in Russian literature (ZABOLOTSKY, 1945). The process of restoring the name of the classics is long in the history of Yakut literature; it is marked by dramatic episodes in the creative history of the major writers of our literature. Only since the appearance of the historical work of G.P. Basharin "Rough sketches about Kulakovsky, Sofronov, Neustroyev", during the Great Patriotic War, the struggle to restore the name of the classics of Yakut literature will begin.

But despite the politicization of critical thinking, young critics and writers, creatively assimilating the experience of Russian literature, strove to follow the experience and traditions of Russian classical criticism, and acquired knowledge of literary theory. In its 
effective striving to create a new literature, Yakut criticism entered the stage of the formation of ideological-aesthetic and literary-philological maturity. In the works of writers-critics, the most important problems of the development of emerging literature were solved, for instance, the problem of the principle of ideological and party nature of literature, the attitude to folklore and the literary heritage of the classics, the problem of the creative method and styles, ways of depicting reality, as well as the problems of artistry and genre.

So, Yakut criticism of this period experienced an unprecedented creative upsurge, trying to turn criticism into a tool of organizing the literary process, which is the specifics of the historical development of young Yakut literature: this is an accelerated path of development at the initial stage of its formation.

Ideological and aesthetic searches of young writers and critics of the period of the birth of Yakut literature can be seen, as exemplified by the activities of A.A. Ivanov-Kyunde, S.R. Kulachikov-Elliaia, prominent representatives of the creative intelligentsia.

In 1926, Kyunde's article "Fatalism, mysticism and symbolism in the works of Yakut writers" was published (KÜNDE, 1926). According to L.R. Kulakovskaya, the biographer of the poet, at the time of Kyunde's article, a period (1926-1937) characterized by the sticking of political labels due to the influence of RAPP's tendencies begins (KULAKOVSKAYA, 2008). Kyunde discusses the role of proletarian culture in the formation of the communist worldview, attitude to work, collective, and liberation from the influence of religion and shamanism. He notes that a Yakut with little or no reading experience, or even just beginning to read, cannot read critically and decipher the meaning of symbols and allegories, which were numerous in the heritage of pre-revolutionary writers (KÜNDE, 1926). In the dramatic works of A.I. Sofronova, the critic sees excellent daily types, the behavior and character of which is positive from the point of view of the requirements of proletarian literature, but their main drawback is rooted in faith in God and spirits. The main characters believe in fate, and a keen Yakut reader can "become infected" with this, which clearly contradicts the proletarian culture. Religious mysticism and belief in the power of destiny and fate, running like a red thread through Sofronov's works, confirm the fact of the author's faith in these forces.

As for the collection of Kulakovsky's poems, mysticism is especially manifested in the poem "The Shaman's Dream", where the hero-author foretells imperialist wars, natural disasters, and the migration of peoples as God's punishment for human actions, which should lead to the extinction of the Yakuts. The critic expresses the fear of "contamination" of the poison of doubt in the economic, cultural, and legal strengthening of the Yakut people under Soviet rule. Kulakovsky's philosophical poem about the fate of the Yakut people in the 
paradigm of human development, surprising in the power of re-creation and the power of the word, was assessed by one of the first critics from a narrow class position, which once again confirms the dependence of criticism on the country's political attitudes. The subsequent destiny of the poem, translated into different languages in the modern period, demonstrated the timeless nature of the creation of the first Yakut poet and thinker (SUZUKI, 2015).

The talented writer and critic Kyunde wrote works on Yakut poetry, in particular "The Artistic Form of Yakut Poetry", which goes back to the principle of studying poetry as an artistic system with its own rules and comparative science of versification in national literatures. Undoubtedly, the pages of the life and creative activity of the son of his time are viewed today as a new approach associated with the revision of ideological, aesthetic, and philosophical views.

S.R. Kulachikov-Ellyay, a poet, one of the first Yakut critics of the Young Bolshevik group, who was the mouthpiece of the RAPP principles in Yakut literature, devoted many articles to the analysis of Kulakovsky's creative work. The group members set out to expose the deviations hostile to the Communist Party and eradicate the influence of the so-called bourgeois writers on the readers. During this period, Kulachikov's attitude to the work of the first poet was contradictory. Even during A.E. Kulakovsky's lifetime, he highly appreciates the poet's work in his article "The Singer of Yakut Life" (1925): "Yakut literature has not known a greater name than Kulakovsky yet [...]. The history of the emerging Yakut literature will consider him the first singer" (KULACHIKOV, 1925). In addition to the important role of Kulakovsky in the development of not only literature, but also science in Yakutia, the critic noted his merits as a researcher in the field of ethnography and, specially, stated his role in the development of the Yakut literary language (KULACHIKOV, 1925).

But the first accusation of Kulakovsky of bourgeois nationalism is also connected with the name of Kulachikov. His article "Bourgeois-nationalist tendencies in modern Yakut literature" (1931) mercilessly criticized the main work of the poet "The Shaman's Dream". The young critic perceived the main character as "an ardent national-chauvinist leader" (KULACHIKOV, 1931).

A year after A.E. Kulakovsky's death, about 20 articles on the artistic heritage of the classic of literature were published. Among them, it is worth noting the article "On literary issues" by S. Donsky under the pseudonym "Novyi (New)", which stands apart even in the context of the underestimation and, even, denial of the merits of pre-revolutionary writers. The critic sees the merit of the classics in the creation of the main genre forms of Yakut literature. He notes that Kulakovsky goes beyond Yakutia in the poem "The Shaman's 
Dream" and the poem "Borokuot aal", touching upon the problems of science and politics in Yakut literature for the first time (NOVYI, 1927). The article also deals with the relationship between the writer and the reader as participants in the literary process, which goes back to the basic position of bibliopsychology of N.A. Rubakin, who considers them as an organic whole. The critic's thought about the peasant (proletarian) writer is interesting regarding a readership. He refutes the widespread opinion that the writer belongs to the peasantry (proletariat) only because he himself comes from the people. The author believes that criticism considers the degree of artistry of the writer's works, his skill in depicting the realities of life, as well as the size of the readership as the key condition for determining the writer's individuality. Based on this, he divides the Yakut writers into two sides: young party writers and pre-revolutionary non-party writers. The first group of writers, although considered peasant in terms of belonging and subject matter of their works, do not have a peasant (folk) reading audience due to the imperfection of literary works, and the second group, not perceiving the revolution ideologically, is more readable by the people, which indicates a greater degree of their folk character (NOVYI, 1927).

Generally, young critics confidently declared that the new Yakut literature should distance from the previous spiritual culture of the people, since it reflects bourgeoisnationalist ideology. But among them there were those who opposed the nihilistic attitude and recognized the merits of the unsurpassed masters of the Yakut literary word in the development of Yakut literature.

\section{Materials and methods}

The research methodology basis is a system-integrated approach to the study of literary phenomena, following the principles and methods of concrete historical analysis, revealing cause-and-effect relationships in critical literature in the works of D.S. Likhachev, N.I. Konrad, V.I. Kuleshov, Yu.B. Borev, M.G. Zeldovich, B.E. Esin and others. The theoretical and methodological basis for the study of literary criticism were the works of B.I. Bursov, V.V. Prozorov, G.A. Stadnikov, M.M. Golubkov, S.P. Istratov and others.

\section{Results}

The study of the critical material about of A.E. Kulakovsky's work in the 1920s and 1930s led to the conclusion that the critics touched upon three main problems: first, 
explaining the subject of fiction and its role in the life of society to a wide reading audience; second, the attitude to the heritage of the classics of Yakut literature and folklore, and third, development paths of the emerging Yakut literature.

Certainly, in the first decades of the last century, Yakut criticism was just emerging; it had more "applied relevance", dealing with a general assessment of an artistic work, identifying its strengths and weaknesses, encouraging or condemning the author. However, by the end of the 1920s, there was an expansion of the very concept of criticism, there were works in which the assessment was based on the interpretation of the work as an artistic whole, which underlies the concept of critical realism.

In terms of the specifics of criticism as such, the works of critics of that period had a close connection with life, with the political, cultural, and aesthetic ideas of those days. From the point of view of modern social and artistic tasks, young writers interpreted the classical heritage of pre-revolutionary writers, passing in their works from literary problems per se to social, public and political problems. Yakut criticism made attempts to guide the cultural life of society, placing the issues of building class fiction at the forefront. We can say that at the initial stage of its formation, the Yakut literary criticism is a very sensitive device that notes even the smallest changes in the political climate.

\section{Discussion}

Within the framework of the chosen aspect of research, we did not consider the works of foreign authors who could expand the horizons of study in the issues of classifying prerevolutionary writers as bourgeois nationalists. In this regard, the book "The Peoples of the Soviet Far East" by American scientists Walter Kolarz and Frederick Praege is of the greatest interest to us (KOLARZ; PRAEGER, 1954). The book found its readers through reprints in the UK, the USA, and India. In the same year, a monograph by W. Kolarz was published, where two chapters deal with Yakut topics: "Yakut Nationalism" and "The Basharin Incident" (KOLARZ, 1954). The point is that out of 5-6 writers of that time, only one can be attributed to the proletarian, and the others are "nationalists". Moreover, Kolarz explains the so-called nationalism as the only weapon in the struggle to preserve the nation for a small intelligentsia under the conditions of an ideological dictatorship. The author calls Kulakovsky the most significant of the nationalists; the essence of his political philosophy is reflected in the poem “The Shaman's Dream". Kolarz notes that the poet's and thinker's warning against the complete assimilation or disappearance of the Yakuts, generally, has substantive reasons, 
which the classic predicts, and there is only one way of salvation from this - the Yakuts' involvement into science and technology.

Moreover, the authors of the first critical articles were poets and writers. This fact demands a separate in-depth study since literary criticism has its own specific features. In addition, the first comments and reviews were published by teachers of the teachers' college and students, as well as representatives of the Yakut intelligentsia interested in the development of literature, which should also be considered separately.

\section{Conclusion}

A brief overview of the assessment of poetic works by A.E. Kulakovsky's, of the emerging Yakut literary criticism, allows us to conclude that the ante mortem criticism of the poet's work was generally objective and positive. Novice critics and writers of young Yakut literature knew Kulakovsky personally, witnessed how his works were spread among the reading public in handwritten collections, albums, and notebooks long before publication. The comments and reviews acknowledged the artistic merit of the poet's works, the form and depth of their content. According to Kulakovskaya (2008, p. 28), "during his lifetime, Kulakovsky was not attacked either for his literary and scientific work, or his political views", and the first critical speeches about the poet's life, work, and activity are "the first manifestations of the depoliticized, de-ideologized Yakut critical thought".

By the mid-1920s, under the influence of the RAPP declarations, the objective approach began to give way to the ideological and class approach, when the understanding of the creative process began to be closely connected with the authors' ideological tendencies, and the concepts of aesthetic taste began to acquire a class orientation, which at first led to underestimation, and then to denial of the first Yakut writers' cultural heritage. The adherence of most critics to the vulgar sociological methodology of the RAPP theorists was expressed primarily in a somewhat simplified interpretation by critics of the very essence of literature as an art form, in a nihilistic attitude towards folklore and the artistic heritage of prerevolutionary writers. This position led not only to the denial of continuity in literature, but also to the orientation of the development of new literature on the principles of a clearly pronounced proletarian class character.

The works of A.E. Kulakovsky, A.I. Sofronov, N. D. Neustroev, and then P.A. Oyunsky were subjected to ideological criticism for a long time during this difficult period in the development of Yakut critical thought. But nevertheless, novice critics also raised 
problems of a methodological nature, for example, the principle of class character in literature and art, the artistic method, and the style of the writer.

Thus, recognizing poetic talent, the scale of categorical philosophical thinking, understanding the depth of the content of A.E. Kulakovsky's works, but guided by the ideological principles dealing with history in literature, Yakut writers and critics of the period of the birth of literature were taking the major exam for recognizing the power of the first Yakut poet's creative works. In this regard, representatives of the Yakut people, who did not have a written tradition, together with other peoples of Russia, started to burst into revolutionary transformations in all areas of material and spiritual life, by trial and error firmly stood on the wing of a literary flight, in order to present an original and unique Yakut literature to the world.

\section{REFERENCES}

KOLARZ, W. The Peoples of the Soviet Far East. New-York, US: Archon, 1954.

KOLARZ, W; PRAEGER, F. A. The Peoples of the Soviet Far East. New York, US: Archon, 1954.

KULACHIKOV, S R. Bourgeois-nationalist tendencies in modern Yakut literature. Autonomous Yakutia, Yakutsk, 1931.

KULACHIKOV, S. R. Sakha olo5un yryahyta. Yakutsk: Kyym, 1925.

KULAKOVSKAYA, L. R. Scientific biography of A.E. Kulakovsky: the personality of the poet and his time. Novosibirsk: Nauka, 2008.

KÜNDE. Fatalism, mysticism and symbolism in the works of Yakut writers. Autonomous Yakutia, Yakutsk, 1926.

KYCLYUMNUR. The Yakuts' literary creativite work. Ilin, Yakutsk, v. 2, p. 10-11, 1991.

LEONTIEV, V. N. Critical notes on the work of A.E. Kulakovsky. Archive of YSC RAS, fund 5, protocol 2, file 162, p. 3-4, 1925.

LEONTIEV, V. N. Is Kulakovsky a poet? Yakut distant lightning, Yakutsk, v. 23, p. 21-23, $1926 b$.

LEONTIEV, V. N. Revolution innineeghi Sakha literaturata. In: RESEARCH SOCIETY SAKH KESKILE. Collection of works "Sakha keskile". Yakutsk: Sakha keskile, 1926a. n. 3, p. 81-87.

NALTAN, M. Yakutskiy Lennrot. Autonomous Yakutia, Yakutsk, 1925. 
NOVYI. On literary issues: (on the articles of Cds Potapov and Leontiev). Autonomous Yakutia, Yakutsk, 1927.

PROTODYAKONOV, V. N. Ayar tyl uottannyn!!! Tyl ilbihe tölönnönnün!!!. KemLiteratura-Törüt üges tuhunan sanaalar. Yakutsk: Bichik, 2009.

RUSSIA. Academy of Science of The Republic of Sakha (YAKUTIA). Literature of Yakutia in the 20th century: historical and literary essays. Yakutsk: Institute for Humanitarian Research of Academy of Sciences of the Republic of Sakha (YAKUTIA), 2005.

RUSSIA. East-Siberian Branch of Russian Geographical Society. Essays on the study of the Yakutsk Territory. Irkutsk: Power of labor, 1927.

RUSSIA. National Archives of the Republic of Sakha (YAKUTIA). Fund 459, protocol 1, file 88 , p. 1-6.

SIVTCEVA-MAKSIMOVA, P.; SIVTSEVA, C. Toward the scientific research of A. E. Kulakovsky: floristic analysis of the northernregion of Russia. Amazonia Investiga, Florencia, v. 8, p. 365-371, 2019. Available:

https://www.amazoniainvestiga.info/index.php/amazonia/article/view/113/89. Access: 10 May 2021.

SIVTSEVA-MAKSIMOVA, P. V. A. E. Kulakovsky as the founder of the Yakut fiction. In: Literature of Yakutia in the 20th century: historical and literary essays. Yakutsk: Bichik, 2005. p. 41-66.

SUZUKI, D. Experience in translating the poem by A.E.Kulakovsky "Shaman's Dream" (1910) into Japanese. Culture and Language. Sapporo: The Faculty of Foreign Languages, Sapporo University, 2015. p. 53-110.

SYROMYATNIKOV, G. S. History of Sakha literary criticism: 1917-1945: Reading book. Yakutsk: North-eastern federal university in Yakutsk, 2017.

ZABOLOTSKY, N. M. A. E. Kulakovskay sakha poeziyatyn chypchaala. Kyym, Yakutsk, 1945. 


\section{How to reference this article}

DARBASOVA, S. Evaluation of A.E. Kulakovsky's writing during the nascent period of Yakutsk literary criticism. Revista Entrelínguas, Araraquara, v. 7, n. 00, e021031, 2021. eISSN:2447-3529. DOI: https://doi.org/10.29051/el.v7i00.15200

Submitted: $15 / 05 / 2021$

Required revisions: 29/05/2021

Approved: 10/06/21

Published: $26 / 06 / 2021$ 